\title{
Estabelecimentos muito úteis nessas montanhas. A produção de mulas no extremo sul do Brasil (c. 1830 - c. 1860)
}

\author{
Very useful establishments in these mountains. \\ The production of mules in the extreme south of Brazil (c. 1830 - c. 1860)
}

\section{Leandro Goya Fontella}

Doutor em História Social pela Universidade Federal do Rio de Janeiro (PPGHiS/

UFRJ); mestre em História pela Universidade Federal do Rio Grande do Sul (PPGH/UFRGS); licenciado em História pela Universidade Franciscana (UFN)

Professor de História do Instituto Federal de Educação, Ciência e Tecnologia Farroupilha - Campus São Borja - RS, Brasil https://orcid.org/0000-0002-0276-3613 leandro-goya@hotmail.com

Fecha de recepción: 3 de diciembre del 2018

Fecha de aceptación: 15 de enero del 2019

Disponible en línea: 24 de mayo del 2019

Sugerencia de citación: Goya Fontella, L. (2019). Estabelecimentos muito úteis nessas montanhas. A produção de mulas no extremo sul do Brasil (c. 1830 - c. 1860).

tiempo\&economía, 6(2), 59-79

doi: http://dx.doi.org/10.21789/24222704.1406

\section{RESUMO}

O texto trata da importância adquirida pela criação de mulas na região da Vila de São Borja, localizada na fronteira-oeste da província do Rio Grande de São Pedro no extremo sul do Brasil Imperial. A metodologia empregada nesse estudo inspira-se nos pressupostos da História Serial que disponibiliza ferramentas adequadas para o tratamento de documentos que 
apresentam informações homogêneas e reiterativas ao longo do tempo. $O$ exame serial de inventários post-mortem da Vila de São Borja entre 1828 e 1858 desvendou que tal atividade esteve amplamente difundida pela malha produtiva da região. Mesmo não atingindo a mesma monta econômica da pecuária bovina, ela representou uma das estratégias mais viáveis para diversificar a produção.

Palavras-chave: criação de mulas, século XIX, Brasil meridional, história econômica Códigos JEL: N56, N96, R1 1

\section{ABSTRACT}

The aim of this text is to reflect on the importance of mule raising in the region of São Borja Village, located on the west border of the province of Rio Grande de São Pedro in the southernmost end of the Imperial Brazil. The serial analyses of the post-mortem inventories of Vila de São Borja between 1828 and 1858 revealed that this activity was widely spread by the productive network of the region. Even though it did not attain the same economic importance as cattle raising, it represented one of the most practicable strategies in order to diversify the production.

Keywords: mule raising, 19th century, Southern Brazil, Economic History

JEL Codes: N56, N96, R11 
"formar-se-iam estabelecimentos muito úteis nessas montanhas, destinados à criação de animais, principalmente de muares" Arsène Isabelle ([1834] 2006, p. 204 [grifos meus]).

\section{Introdução}

Criada em 1833, a Vila de São Borja, sítio de interesse específico deste artigo, herdou boa parte da extensão territorial que compreendia as áreas pertencentes aos Sete Povos das Missões Orientais do rio Uruguai, os quais haviam passado à jurisdição portuguesa em 1801. 0 território da referida vila contava com uma ampla área de campos que acompanhava as extensões dos rios Uruguai e Ibicuí bastante adequados ao pastoreio do rebanho bovino. Porém, na porção mais oriental do município havia também um considerável espaço de relevo mais acidentado, coberto por florestas nativas, onde provavelmente concentravam-se as lavouras de alimentos e a criação de mulas.

Figura 1. Mapa Físico do Rio Grande de São Pedro e localização da Vila de São Borja

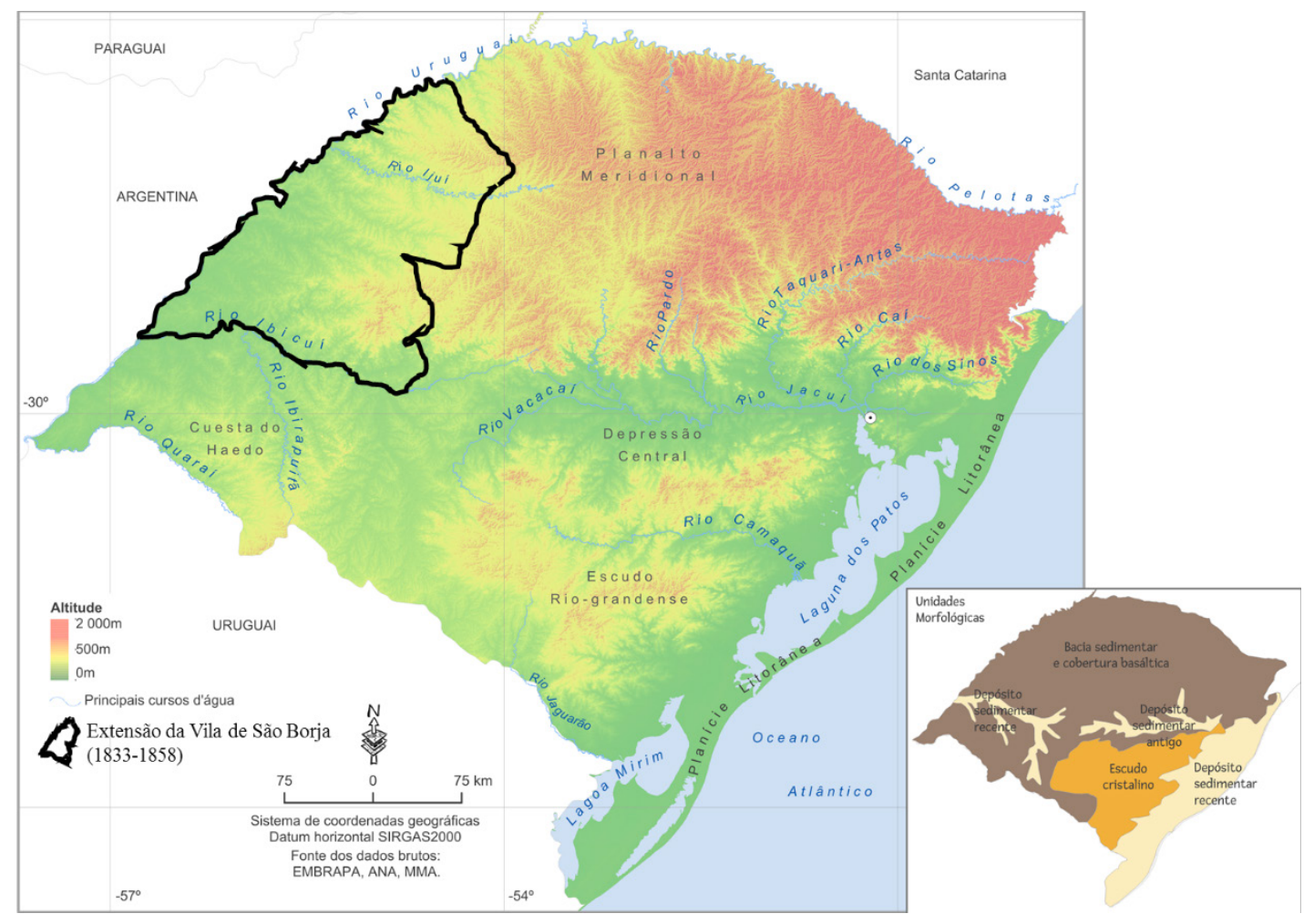

Fonte: Adaptação de imagem retirada de PESSOA, M. L. (Org.). RS Físico. In Atlas FEE. Porto Alegre: FEE, 2017. Disponível em http://atlas.fee.tche.br/rio-grande-do-sul/geral/rs-fisico/. Acesso em 17 de dezembro de 2018.

tiempo\&economía

Vol. 6 N. ${ }^{\circ} 2$ - Julio - Diciembre del 2019

p. 61 
Além do fragmento destacado como preâmbulo deste texto, durante sua passagem pela fronteira-oeste do Rio Grande de São Pedro entre dezembro de 1833 e fevereiro de 1834, o viajante francês Arsène Isabelle anotou que "toda a campanha ${ }^{1}$ próxima ao Piratini [afluente do rio Uruguai] é acidentada e as pastagens são adequadas à criação de cavalos, mulas e animais lanígeros. Faz-se grande comércio de muares com a vizinha província de São Paulo" ([1834] 2006, p. 201 [grifos meus]).

O vínculo comercial com o mercado paulista se dava principalmente por meio da Feira de Sorocaba, onde os animais eram destinados a várias áreas do império brasileiro. Contudo, esta ligação, compõe apenas uma parte de um vasto complexo produtivo-mercantil que em seus primórdios ainda no século XVII conectava uma complexa cadeia de agentes que se espalhava desde Buenos Aires até o centro minerador de Potosí e, num segundo momento (séculos xvIII e XIX), se deslocou para o eixo que ligava Buenos Aires/Montevidéu à Minas Gerais no Brasil. Este deslocamento se insere no contexto de paulatina transformação econômica que Alejandra Aragoin e Roberto Schimt (2003) chamaram de desintegração da economia colonial da América meridional. Segundo os autores, tal transformação se caracterizou não por uma ruptura drástica com os complexos produtivos coloniais, mas sim por respostas concretas (com mudanças e continuidades) que cada região deu ao irresistível processo de avanço de um sistema econômico que tinha como lógica a integração do mercado mundial que se definia, entre outras coisas, por uma divisão internacional do trabalho em que áreas periféricas como a América do Sul deviam produzir e fornecer produtos primários às econômicas europeias em vias de industrialização -sobretudo a Grã-Bretanha.

Tanto a mineração da prata em Potosí quanto do ouro nas Minas Gerais e Goiás criaram a demanda por animais de carga para atender as necessidades de transporte dos metais exportados e das mercadorias que ingressavam nas referidas regiões. Segundo Luiz Carlos Borges,

o auge do comércio de mulas na feira de Salta [extremo norte do atual território argentino] coincide com o aumento da negociação de animais no sul do Brasil, graças às ampliações da demanda no centro-sul em virtude do ouro das Minas Gerais. (Borges, 2016, p. 212)

Dados levantados por Gustavo L. Paz (1999, p. 48) mostram que durante o auge do comércio de mulas, entre 1765 a 1779, por ano passavam em média cerca de 33 mil cabeças e de 1795 a 1808, este número foi de 31 mil. Paz apresenta o itinerário percorrido pelas tropas muares. Segundo o autor, o nascimento das mulas se dava nos campos buenairenses e ao sul de Santa Fé onde permaneciam até por volta de 2 anos quando eram levadas em tropas de 600 a 700 cabeças até Córdoba para serem vendidas a invernadores e negociantes que as mantinham ali por cerca de 14 meses para maturação. Findado esse período, rebanhos de 1300 a 1400 muares dirigiam-se até as redondezas de Salta, onde invernavam novamente por volta de mais oito meses para engordar antes de serem comercializadas na grande feira anual daquela localidade (Paz, 1999, p. 50).

1 A expressão campanha foi utilizada com o sentido de extensão de campo e pastagens. 
Por sua vez, María Victoria Márquez também defende que em meio a todo esse circuito produtivo-mercantil das mulas que ligava os campos de Buenos Aires, as regiões de Santa Fé, Córdoba e as zonas mineiras do Brasil estava a zona das missões guaraníticas (de qual o espaço da futura Vila de São Borja fazia parte). Para a autora, Santa Fé se constituía como entreposto das diversas rotas que ligavam o interior, a zona das missões e o Paraguai com o Atlântico. Em razão disso, no século xvIII, para além de ser um importante polo de criação de mulas e de pecuária bovina, esta localidade desempenhava o papel estratégico de intermediação mercantil (Márquez, 2008, p. 108). Guillermo Wilde assinala que no ano de 1751, na redução de "La Cruz... alguns guaranis não cumpriram a ordem de tirar mulas para despachá-las ao Rio Grande" (2009, p. 208) [tradução livre].

A produção muar no Rio Grande de São Pedro (extremo meridional do Brasil) começou apenas nos anos 1750, até então, as mulas eram trazidas de regiões hispânicas como Salta, Tucumã, Santa Fé, Córdoba e Buenos Aires (Garavaglia, 1999, p. 217; Hameister, 2002, p. 224). De tais centros produtivos, os criadores sul rio-grandenses importaram animais e tecnologia (Borges, 2016, p. 209). Paradoxalmente, foi justamente a partir deste momento do Setecentos que a produção de ouro das Minas Gerais passou a uma tendência de estagnação. Entretanto, o vigor da economia mineradora sustentou por algumas décadas a demanda pelas bestas produzidas no Prata especialmente para o atendimento do setor de importação. Paulatinamente, as mulas passaram a ser direcionadas para as regiões canavieiras e, posteriormente, cafeeiras que também utilizaram os muares para o escoamento da produção. Nas palavras de Carlos $\mathrm{E}$. Suprinyak e Cristiano C. Restitutti:

a comercialização de bestas de carga do Rio Grande no centro-sul do Brasil não arrefeceu com a decadência da mineração nas últimas décadas do século XVIII e subsequente acomodação econômica ao hinterland do Rio de Janeiro. A manutenção de um sólido setor mercantil na distribuição das importações, assim como a exportação de novos produtos coloniais como o açúcar, contribuiu para manter a demanda por animais em trajetória ascendente. $(2006$, p. 9)

No mesmo sentido, Borges argumenta que em território brasileiro, as mulas se fizeram urgentemente necessárias para atender o transporte de minérios das Minas Gerais. Porém mesmo com a decadência da economia mineradora, a comercialização destes animais no centro-sul se manteve, fazendo com que a produção aumentasse até meados do Oitocentos. Neste contexto, o Rio Grande de São Pedro desempenhou um papel de destaque no cenário produtivo de muares (Borges, 2016, p. 217).

Por volta do período abordado neste texto (c. 1830 - c. 1860), a criação de mulas compunha uma importante atividade da matriz produtiva da região. No decorrer das três primeiras décadas do Oitocentos, a estrutura agropastoril de base privada ali erigida reproduzia o modelo econômico existente na maioria das áreas de pecuária extensiva do Rio Grande de São Pedro. Destacava-se o pastoreio bovino, o qual nas grandes estâncias assentou-se sobre uma estrutura laboral que envolvia a combinação da mão de obra de escrava ${ }^{2}$ e livre, ajustadas numa

2 Em função da dimensão que deve obedecer este artigo, não tratarei sobre a estrutura laboral estabelecida sobre a matriz produtiva da região das Missões. Estudos têm demonstrado que o trabalho escravo esteve disseminado pelo tecido social, desfrutando de ampla legitimidade por todos os estratos econômicos, e configurando-se como a forma de mão de obra estável mais segura e funcional para os produtores. Ademais, a 
dinâmica de trabalho regular e eventual, a qual obedecia a um calendário produtivo pautado pelas estações do ano que exigiam atividades permanentes e outras sazonais. ${ }^{3}$ Outro traço marcante é que tal estrutura econômica ficou marcada pela distribuição bastante desigual dos recursos econômicos pela malha social.

A metodologia empregada nesse estudo inspira-se nos pressupostos da História Serial, campo da ciência histórica que tomou seus contornos teórico-metodológicos mais sofisticados na segunda fase do Movimento dos Annales 4 -entre os anos 1946 e 1969- com Ernest Labrousse e seus discípulos, em especial, François Furet e Adeline Daumard. A partir de então a História Serial adquiriu contornos mais específicos com a elaboração de uma matriz metodológica rigorosa que para além da História Econômica foi aplicada em outros campos da disciplina histórica como, por exemplo, a História Demográfica e das Mentalidades atingindo seu apogeu nos anos 1950 e 1960.

Entretanto, os questionamentos sobre as fragilidades teórico-metodológicas não tardaram a aparecer. Segundo Hebe Mattos, "apesar dos expressivos resultados, a quantificação corria o risco de transformar-se em panaceia. O reconhecimento de seus limites metodológicos e teóricos está na base da evolução da disciplina nas décadas de 1970 e 1980" (Mattos, 1997, p. 83). A crise dos grandes paradigmas estruturalistas - matrizes marxistas, braudeliana e funcionalista- desencadeou-se, por consequência, sobre a História Social e Econômica de base serial-quantitativa. A principal crítica recaiu sobre a incapacidade que os estudos que se utilizavam quase exclusivamente de dados agregados tinham de contemplar em suas análises a esfera das experiências humanas e, por conseguinte, os diferentes graus de autonomia da ação humana frente aos condicionantes estruturais de cada organização social.

No contexto da historiografia brasileira, a abordagem serial faria "sucesso durante toda a década de 1980, ou mesmo durante a década de 1990... Depois, também declina, ou ao menos perde a centralidade que antes tivera em certos domínios historiográficos" (Barros, 2012, p. 214). Sem dúvida, o prolongamento deste sucesso na historiografia brasileira se deve em boa parte ao núcleo historiográfico sobre a História Agrária fluminense, surgido em fins dos anos 1970 e tendo como principal referência a História Social francesa oriunda do movimento dos Annales. Entre outras coisas, os estudos ligados a esta corrente vieram a demonstrar a importância e o dinamismo das produções voltadas ao mercado interno, a disseminação das relações escravistas para muito além das atividades produtivas destinadas à exportação, a diversidade dos grupos sociais externos as áreas de plantations e a reprodução de uma hierarquia social em contextos históricos diversos. ${ }^{5}$

apropriação da mão de obra cativa reproduziu o padrão visto em todo o Brasil imperial, isto é, uma estrutura agudamente desigual, em que poucos senhores que possuíam muitos escravos dividiam espaço com muitos pequenos escravistas que detinham poucos cativos. Portanto, neste texto, parte-se desta avaliação sobre o papel do trabalho escravo na região das Missões. Ver Fontella (2013).

3 Sobre a combinação de trabalho livre e escravo em função da dinâmica de trabalho regular e eventual ver Osório (2007), Farinatti (2010), Fontella (2013).

4 Sobre o Movimento dos Annales, ver Burke (1991), Dosse (1992), Reis (2000).

5 Dentre os mais representativos trabalhos dessa vertente historiográfica destacam-se: Faria (1998), Fragoso (1992), Mattos $(1995,2009)$. Para um ótimo exame a respeito da produção historiográfica em História Agrária sobre o processo histórico brasileiro e suas bases teóricas e metodológicas ver Linhares (1997). 
Em se tratando da historiografia que aborda o processo histórico sul rio-grandense, desde fins dos anos 1980, alguns historiadores têm sido influenciados pela História Agrária Fluminense. ${ }^{6}$ Assim, a partir dos recursos disponibilizados principalmente pela história agrária, autores como Paulo A. Zarth $(1997,2002)$ e Helen Osório (2007), por meio do exame sistemático de uma série diversificada de documentos, deram início a uma série de estudos que vem redefinindo a imagem do universo agrário do Rio Grande de São Pedro. Ademais, Helen Osório e Luís Augusto Farinatti foram diretamente influenciados pela produção historiográfica argentina das últimas décadas sobre o espaço agrário rio-platense. Desde meados da década de 1980 um grupo de historiadores argentinos vem produzindo estudos assentados sobre maciça base empírica, ${ }^{7}$ tendo como referência principal a Escola dos Annales, especificamente sua corrente de História Regional - surgida do diálogo com a geografia humana e desenvolvida entre as décadas de 1930 e 1960. Essa nova historiografia platina renovou a visão sobre o universo rural da região do Prata no período colonial e na primeira metade do século XIX.

Os expedientes metodológicos que emprego nesta pesquisa são semelhantes aos utilizados por estes autores, com os quais estabeleço constante diálogo. Irei concentrar-me na importância que a pecuária muar adquiriu na Vila de São Borja, analisando as características mais relevantes do complexo de produção de gado muar que ali se estabeleceu ao longo do período aproximado de 1828 a 1860. Os dados foram coletados principalmente em inventários post mortem abertos na Vila de São Borja e no Distrito de São Patrício de Itaqui. Analisou-se todos aqueles abertos em anos pares, assim, conformou-se uma amostra de 110 inventários. As informações extraídas foram submetidas, sobretudo, ao método serial-quantitativo. $\mathrm{O}$ texto ficou dividido em dois tópicos, no primeiro trato da complexidade do processo de produção de animais muares, no segundo aborda-se os principais contornos assumidos por tal complexo produtivo e, por último, reservei um espaço para as considerações finais.

\section{A criação de mulas: um processo produtivo complexo}

Embora seja bastante complicado estimar com precisão a representatividade e o volume da produção da pecuária muar no conjunto da atividade pastoril das estâncias e, por conseguinte, da região em análise, estabeleci alguns parâmetros para demonstrar como esta atividade era amplamente desenvolvida. Além da presença das próprias mulas, se pode identificar que um estabelecimento se dedicava a pecuária muar através da presença de animais envolvidos na produção daquelas. Seguirei, portanto, os passos indicados por Mariana Canedo (1993) e Helen Osório (2007). Para examinar qual envergadura adquiriu a produção de mulas na Campanha de Buenos Aires na segunda metade do século XVIII, Canedo considerou sob a rubrica muar tanto os animais muares quanto os asininos.

6 Destaco Farinatti (2010), Osório (2007), Zarth (1997, 2002). Não farei uma análise historiográfica das obras destes autores, pois ao longo do artigo estabeleço um constante diálogo com elas.

7 Entre outros: Garavaglia (1999), Gelman (1998), Djenderedjian (2003), Schmit (2008), Irigoin e Schmit (2003), Bragoni (2004), Carbonari (2013), Fernández (2007), Fernández e Dalla Corte (2005), Girbal-Blacha (2006), Girbal-Blacha (2007), Moreyra (1992), Richard-Jorba e Bonaudo (2014). Para um levantamento historiográfico acerca da historiografía colonial platina (Uruguai e Argentina) até fins dos anos 1990, ver (Osório, 2007, pp. 32-37). 
A produção de mulas não ocorre de forma natural. A mula é um animal híbrido que surge do cruzamento entre burros (gado asinino) e éguas (gado equino). Portanto, se tratava de

um processo complexo, que passa pela separação dos rebanhos de distintas espécies - os asininos e os equinos - sub-repartidos por sexo, isolados dos reprodutores de outros animais de sua própria espécie, requerendo vigilância constante para não pôr a perder o burro reprodutor (burro hechor). [Este animal era bastante valorizado, pois recebia um] adestramento e tratamento especial desde o seu nascimento, para posterior cobertura de éguas, também condicionadas desde filhotes à aceitação dos burros reprodutores. As éguas para este tipo de produção receberam também uma designação própria, chamadas de éguas de cria, éguas de cria de mulas ou éguas de ventre. (Hameister, 2002, p. 75)

É importante destacar que a complexidade do processo produtivo do gado muar exigia que uma considerável quantidade de braços fosse empregada em tal atividade. Conforme Mariana Canedo, "as peculiaridades da produção implicam o insumo de mão de obra fixa e estacional, muito superior ao que exige a exploração do vacum" (1993, p. 159) [tradução livre].

Neste estudo, todos os inventários que continham burros hechores, burros e/ou éguas em cria de mula foram considerados como uma unidade produtora de gado muar. Por sua vez, de forma mais pormenorizada, Paulo Zarth colocou que,

convém analisar que a produção de muares estava estreitamente ligada à criação de fêmeas cavalares - as éguas - que são as matrizes para a criação daqueles [...]. Dessa forma, os animais cavalares que aparecem na figura são na maioria matrizes destinadas à criação de mulas, estas de extrema importância no mercado da época. Ou seja, os cavalares, na verdade, não tinham a importância da mula no mercado. Essas condições podem induzir a erros de avaliação e creditar exagerada participação de animais cavalares em relação aos muares, em termos de importância comercial. Por isso, nos inventários post-mortem é mais provável que se encontre maior quantidade de éguas do que de mulas. A importância das bestas em termos econômicos pode ser medida pelo preço: uma mula era vendida, em 1861, pelo preço médio de quinze mil réis e uma égua valia em torno de 2,5 mil réis. Assim, podemos afirmar que o gado vacum e o gado muar eram os mais importantes animais comercializados pelas estâncias, até o final do século XIX. (Zarth, 1997, p. 109)

A importância comercial das mulas se deve à alta capacidade de carga deste animal provinda de suas características físicas. Vale enfatizar que a mula foi o principal meio de transporte de carga terrestre em toda a América Latina pré-industrial. Segundo Canedo,

as mulas se caracterizam por sua resistência: sua rusticidade lhe permite suportar o clima duro e o trabalho esgotador, com poucos riscos de enfermidade. Devido à grande resistência de suas patas se atribui a elas a possibilidade de carregar mais que um cavalo de seu mesmo tamanho. Tem ademais, um coeficiente de digestão para a celulose muito maior que o cavalo, o que lhe permite aproveitar alimentos más 'grosseiros' e baratos. Também é importante sua inclinação para comer só o que necessita, gerando imunidade a enfermidades e distúrbios digestivos. Sua longevidade é grande como a do asno: rende ao máximo dos 3 anos e meio a 5 , persistindo até os 20 e mais (o cavalo chega até os 15). (1993, p. 155) [tradução livre]

Acrescenta-se também que tais animais eram, talvez, os únicos capazes de se embrenhar em picadas íngremes. Devido a isso, as mulas foram largamente utilizadas para o transporte 
de cargas desde os tempos coloniais. As regiões de grandes lavouras voltadas à exportação no sudeste e nordeste, além das áreas mineradoras, eram os principais centros consumidores do gado muar.

O Rio Grande de São Pedro se vinculou ao circuito produtivo e comercial do gado muar na segunda metade do século XVIII. Conforme Helen Osório,

no mais antigo recenseamento de rebanhos, o de 1741, produzido quatro anos após a fundação de Rio Grande, os animais foram simplesmente divididos entre 'vacas, éguas e ovelhas', não constando muares, cuja criação não deveria ser significativa naquele momento inicial; as tropas de bestas do rio da Prata atravessavam o território até chegarem aos mercados paulistas e mineiros. Quando da tomada de Rio Grande, 22 anos mais tarde, no entanto, eles já representavam, nos territórios que foram perdidos pelos portugueses, $1 \%$ dos animais e 7,4\% do valor do rebanho total. (2007, p. 118 [grifos da autora])

A partir desse momento, paulatinamente, os produtores sul rio-grandenses passaram a investir na produção de muares. Segundo Luís A. Farinatti,

no meado do século XIX, o principal destino dos muares produzidos no Rio Grande do Sul seguia sendo a Feira de Sorocaba, de onde eram encaminhados, principalmente, para as regiões cafeicultoras do Rio de Janeiro e, depois, de São Paulo. [...]. [...] ainda que a principal produção de muares se fizesse no norte da província, nos municípios de Cruz Alta e Passo Fundo, a Campanha não estava fora desse circuito. [...]. O número de mulas comercializadas na Feira de Sorocaba ascendeu, continuamente, ao longo da primeira metade do século XIX, tendo dado um salto na década de 1850, retrocedendo a partir da década de 1860, até entrar em profunda crise, quando da difusão das ferrovias no final do século. (2010, p. 118)

Ao longo de todo esse período que se estendeu desde meados do século XVIII até fins do século XIX a criação de muares se erigiu em uma possibilidade de diversificar a produção no interior das estâncias. Nas próximas páginas, buscarei, por meio dos inventários post-mortem, perceber suas características e a dimensão que tomou.

\section{A criação de mulas: um complexo produtivo}

Na Vila de São Borja, ao longo do período investigado, dos 110 inventários examinados, em 106 deles foram descritos animais de algum tipo de rebanho. Entretanto, destes, excluí o inventário de Silberto Teixeira da $\mathrm{Luz}^{8}$ e Joana Dias, ${ }^{9}$ ficando 104 inventários na amostra sobre a qual realizarei a apreciação da pecuária muar. Destes 104 inventários contemplados na análise, encontrei indícios de criação de gado muar em 71 deles. Em termos proporcionais este número representa $68 \%$. Em 50 inventários foram descritos burros hechores e mulas, em outros 15 foram arrolados apenas burros hechores e nos 6 inventários restantes alistaram-se somente mulas. De todos estes 71 produtores, somente Antônio José Guimarães não conciliava a criação de muares com a pecuária bovina. O inventário deste sujeito foi aberto no ano de 1848 e

8 Detinha apenas dois animais vacuns e nenhum outro tipo de animal. Além disso, seus bens eram compostos de instrumentos agrícolas e atafona, portanto, acredito que esse indivíduo se dedicava quase que exclusivamente a agricultura.

9 Possuía apenas 4 animais cavalares, portanto, não considerei como criadora.

tiempo\&economía

Vol. 6 N. 2 - Julio - Diciembre del 2019

p. 67 
contava com 104 éguas chucras, 8 potros, 40 ovelhas, 8 mulas de marca e 1 burro hechor. ${ }^{10}$ Os outros 70 produtores de muares também praticavam a criação de gado bovino. Isto sugere que a criação de muares esteve consideravelmente difundida, se erigindo como uma possibilidade de diversificar a produção no interior das estâncias e, consequentemente, de matizar a matriz produtiva da região. Este dado está em consonância com o cenário produtivo da campanha buenairense na segunda metade do Setecentos. Mariana Canedo averiguou que naquela região,

não há produtores registrados especializados em um tipo de pecuária que exclua os outros tipos, ou a produção agrícola ou outras atividades. Os criadores de mulas dos Arroyos são gado, eles têm cavalos, alguns têm bois e muitas ovelhas, eles também cultivam ou arrastam com seus carrinhos... [Assim] a produção de mulas não é provativa de um determinado setor social; Além disso, os casos analisados mostram que essa atividade atravessa a estrutura social da área. (1993, pp. 156-157) [tradução livre]

Diante as incertezas daquele mundo, os produtores tinham de elaborar estratégias para aumentar suas margens de seguranças frente a um contexto histórico repleto de vicissitudes (Levi, 2000). Talvez, para eles, a criação de mulas tenha se apresentado como uma das estratégias mais viáveis para diversificar a produção e, em consequência, ampliar seu leque de possibilidades econômicas e produtivas para, assim, se tornar menos vulneráveis as precariedades do universo em que estavam inseridos.

Ao verificar que $48,3 \%$ do rebanho de Cruz Alta era composto por animais cavalares, muares e asininos, Thiago Araújo argumenta que,

a produção e o comércio de gado vacum e de gado muar eram as atividades pecuárias de maior importância na região [do Planalto], embora a produção de mulas fosse muito mais importante na vila quando comparada com outras regiões do Rio Grande... Essa diversificação do rebanho por parte dos criadores é uma especificidade econômica importante... [e] somada à prática intensiva da agricultura [...] dotava a vila [de Cruz Alta] de um pouco mais de elasticidade para enfrentar as conjunturas de baixa no mercado pecuário, o que talvez possa explicar, em parte, a continuidade e a importância da escravidão para a maioria dos estancieiros as vésperas da abolição. (Araújo, 2008, pp. 41,43)

Como já argumentei, é bastante difícil elaborar uma projeção do volume da produção muar. No entanto, creio que se uma atividade significativamente complexa, que exigia um considerável grau de especialização e investimento (monetário, de tempo, mão-de-obra, etc.), estava disseminada por boa parte dos estabelecimentos produtivos, era porque se apresentava comercialmente atrativa e, também, economicamente viável. Logo, os volumes de produção não deveriam ser desprezíveis, pois cada produtor buscaria retirar de seus investimentos um resultado minimamente aceitável.

Obviamente, não considero estes criadores de meados do século XIX dotados de uma racionalidade econômica capitalista que visa a maior racionalização produtiva e otimização do lucro. Porém, acredito ser inegável que mesmo munidos de uma racionalidade específica, a

10 Inventário de Antônio José Guimarães. Fundo 102, Comarca de Missões, localidade: São Borja, Subfundo: Cível e Crime, ano: 1848, processo no: 04, Arquivo Público do Estado Rio Grande do Sul [doravante, APERS]. 
qual não seria regida apenas pelos ditames do mercado e que, sem dúvida, levaria em conta diversos fatores extra-econômicos, todos aqueles produtores buscavam obter resultados minimamente suficientes em suas atividades produtivas. Afinal, seria por meio destes resultados que conseguiriam reduzir suas incertezas naquele contexto repleto de precariedades (como as guerras, intempéries climáticas, pestes, etc.) e, assim, se conservarem inseridos em ambientes estáveis, onde pudessem organizar suas vidas dentro de um horizonte de previsibilidade, o qual se buscava constantemente aprimorar (Espada Lima, 2005; Levi, 2000). Já para a região da Campanha, Farinatti aponta que,

em Alegrete, os muares, que nos períodos anteriores estiveram presentes em 40 a $45 \%$ dos inventários, ampliaram um pouco sua presença para 55\% na década de 1850 e voltaram para os padrões anteriores no decênio seguinte. Essa pequena ampliação na difusão da criação de mulas e seu retrocesso posterior se deveram a uma conjuntura favorável no mercado sorocabano e à crise que lhe sucedeu. (Farinatti, 2010, p. 118)

Os dados apresentados pelo autor estão, consideravelmente, aquém dos que levantei para a Vila de São Borja. Se em Alegrete o gado muar esteve presente no máximo em 55\% dos estabelecimentos produtivos, fato ocorrido nos anos 1850, em São Borja, a presença dos animais muares nas unidades produtivas jamais foi menor do que $60 \%$, índice constatado na década de 1840. Os números apresentados na tabela 1 comprovam a importância da criação de mulas em São Borja.

Tabela 1. Presença do gado muar nos inventários, Vila de São Borja

\begin{tabular}{lcccccc}
\hline & \multicolumn{6}{c}{ Inventários } \\
\cline { 2 - 7 } & \multicolumn{2}{c}{$1828-1840$} & \multicolumn{2}{c}{ Década de 1840 } & \multicolumn{2}{c}{ Década de 1850 } \\
\cline { 2 - 7 } & $\mathrm{n}^{\circ}$ & $\%$ & $\mathrm{n}^{\circ}$ & $\%$ & $\mathrm{n}^{\circ}$ & $\%$ \\
\hline Com criação muar & 8 & $67 \%$ & 21 & $60 \%$ & 42 & $74 \%$ \\
Sem criação muar & 4 & $33 \%$ & 14 & $40 \%$ & 15 & $26 \%$ \\
& 12 & $100 \%$ & 35 & $100 \%$ & 57 & $100 \%$ \\
\hline
\end{tabular}

Fonte: Inventários post-mortem da Vila de São Borja (1828-1858) e do Distrito de São Patrício de Itaqui (1830-1858), APERS.

Apesar da variação negativa ocorrida do primeiro para o segundo intervalo, quando a representatividade dos criadores de muares caiu de $67 \%$ para $60 \%$, no último, estes produtores aumentaram sua presença para 74\%. Os números verificados nos anos 1850 são bastante expressivos pois além de $55 \%$ da amostragem se concentrar neste período, eles expressam o cenário econômico após o fim da série de conflitos que afetou por cerca de 4 decênios (contendas ligados ao processo de emancipações políticas dos Estados platinos e controle do espaço guaranítico missioneiro até cerca de $1830^{11}$ e Guerra dos Farrapos na província do Rio Grande

11 A partir de 1810, todo o espaço platino passou a ser sacudido por uma onda revolucionária que promoveu as emancipações políticas dos territórios até então subordinados à Espanha e à Portugal. Estes incidentes mergulharam a região platina num processo de endemia bélica que se estenderia por várias décadas, primeiro com as batalhas pela autonomia política entre exércitos revolucionários e dos Impérios ibéricos, depois os conflitos entre diversos projetos para as novas sociedades emancipadas e, também, entre os novos países 
de São Pedro entre 1835 e $1845^{12}$ ). Desse modo, não deixa de ser significativo que a criação de mulas se mostrasse tão difundida e consolidada na região já nos primeiros momentos em que a região vivia sem aberta deflagração bélica.

Visto a importância da produção muar, é preciso esboçar algumas características da estrutura produtiva desta atividade criatória. Para isso, irei estabelecer uma relação entre a pecuária muar e a vacum. Daqueles 71 inventários onde encontrei indícios de criação de gado muar, tive que excluir desta análise específica um deles, o processo de Antonio José Guimarães. ${ }^{13}$ Isto ocorreu porque este sujeito não possuía animais vacuns. Consequentemente, não pôde ser classificado em uma faixa de envergadura de rebanho vacum. Desse modo, os dados da figura 2 foram elaborados por meio de uma amostragem de 70 inventários de produtores que se dedicavam a ambas as criações.

Em primeiro lugar, é preciso colocar que para efeito de análise considerarei três estratos de criadores, são eles: pequenos criadores, aqueles que possuíam rebanhos com até 500 bovinos; médios criadores, que eram donos de rebanhos de 501 a 2000 bois; e, por fim, grandes criadores, os quais detinham mais do que 2000 cabeças de gado vacum. ${ }^{14}$ A partir disso, constatei que em todo o período, $50 \%$ dos produtores de mula eram pequenos criadores de animais vacuns, $30 \%$ eram médios criadores e o restante, $20 \%$, eram grandes criadores. No entanto, os dados mais interessantes sobre a presença dos criadores de mulas estejam nas importantes transformações pelas quais passou a estrutura produtiva de gado muar no decorrer das três décadas examinadas.

Figura 2. Criação de mulas de acordo com a envergadura do rebanho bovino, Vila de São Borja

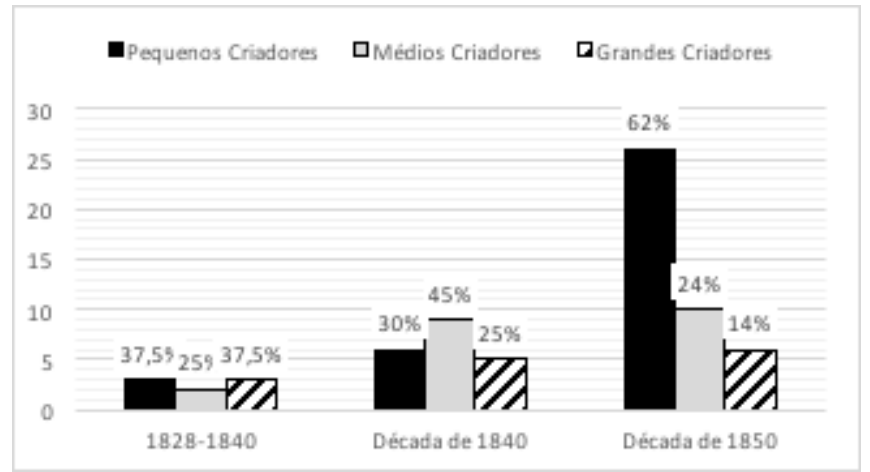

Fonte: Inventários post-mortem da Vila de São Borja (1828-1858) e do Distrito de São Patrício de Itaqui (1830-1858), APERS.

americanos recentemente estabelecidos. Destaca-se: os conflitos envolvendo o caudilho José Gervásio Artigas nos anos 1810, a Guerra da Cisplatina (1825-1828). Sobre o movimento artiguista ver: (Frega, 1998). Sobre a Guerra da Cisplatina ver Carneiro (1983), Frega (2009). Sobre o processo emancipatório das Repúblicas platinas ver Chiaramonte (1997).

12 Guerra Civil ocorrida na Província do Rio Grande de São Pedro, opondo parte da elite pecuarista sul rio-grandense e o Império do Brasil. Entre outros ver: (Dacanal, 1997; Leitman, 1979).

13 Inventário de Antônio José Guimarães. Fundo 102, Comarca de Missões, localidade: São Borja, Subfundo: Cível e Crime, ano: 1848, processo: n 04, APERS.

14 Estabeleci essas faixas com base na classificação elaborada por Luís Augusto Farinatti (2010, pp. 149-150). 
Na figura 2, relacionei as diferentes dimensões dos rebanhos vacum com a presença de produção de gado muar. Embora tenha que se considerar os dados do primeiro intervalo com reservas devido o reduzido número de inventários que compõem a amostra, pode-se perceber que a produção de mulas parecia ser uma atividade que despertava o interesse em todos os criadores de animais bovinos, independente da dimensão do rebanho. A estrutura produtiva da pecuária muar, no período de 1828 a 1840, contava com produtores entre as três faixas de envergadura dos criadores de gado vacum, pequenos e grandes criadores representavam cada um $37,5 \%$ dos produtores de muares enquanto que os médios perfaziam os $25 \%$ restantes.

No decorrer do período, a estrutura produtiva da produção muar passou por importantes transformações. Na década de 1840 os médios passaram de $25 \%$ para $45 \%$ dos criadores de mulas, enquanto que grandes e pequenos perderam representatividade, $30 \%$ para estes e $25 \%$ para aqueles. Por fim, nos anos 1850 , os pequenos criadores de bovinos saltaram para expressivos $64 \%$ dos produtores de mula, os médios tinham se reduzido a $24 \%$ e os grandes voltaram a cair, alcançando apenas $14 \%$ dos criadores de mula.

Em síntese, ao longo do período que abordo, o universo produtivo da pecuária muar passou a ser composto em grande parte por pequenos criadores de animais bovinos. Notem que isto não significa dizer que os pequenos criadores concentravam a posse do gado muar. Muito provavelmente, se existisse informações confiáveis para elaborarmos uma estrutura de posse de gado muar, ela seria bastante semelhante à estrutura de posse do gado bovino (Fontella, 2014). Ou seja, haveria uma pequena elite de grandes produtores de muares, que concentrariam a maior parcela do rebanho, dividindo espaço com uma legião de pequenos produtores, que dividiriam entre si uma pequena fatia do montante de mulas. Vale ressaltar ainda que, como os inventários são fontes que tendem a sobre representar os estratos sociais mais abastados, pois em muitas ocasiões os escassos bens de sujeitos e/ou famílias pobres não eram inventáriados devido aos custos do processo, provavelmente a presença de médios e sobretudo pequenos criadores de mula esteja sub-representada especialmente nos anos 1830 quando a amostra é exígua. Portanto, a quantidade de pequenos e médios produtores de muares naquele universo devia ser consideravelmente maior do que os números obtidos pelos inventários.

No que tange à frequência com que os produtores desenvolviam a pecuária vacum e a pecuária muar, constatei que 99 dos 104 inventários eram de criadores de bovinos e que neste universo 69 (70\%) também se dedicavam a produzir mulas. ${ }^{15}$ Para o período colonial, utilizando-se de inventários post-mortem, Helen Osório constatou que entre os estancieiros, produtores que possuíam mais de cem cabeças de gado vacum, "47\% criavam muares, sendo essa proporção de $42 \%$ entre os estancieiros médios e $60 \%$ entre os grandes estancieiros" (2007, p. 123). Refinando sua análise, a autora coloca ainda que:

a importância dos muares é notória no primeiro subperíodo, 1765-1785, quando representavam $24 \%$ do valor total do rebanho, sendo criados por $56 \%$ dos estancieiros. Porém, nos períodos subsequentes, essa atividade decaiu bruscamente até que, entre 1815-1825, não ultrapassava 1,5\% do valor do rebanho, e apenas 36\% dos estancieiros praticavam-na (Osório, 2007, p. 123)

15 Da amostra de 104 inventários que contava com algum tipo de rebanho excluímos cinco, pois não possuíam gado vacum suficiente pare serem considerados como criadores de bovinos. Portanto, a figura 3 foi elaborada a partir de uma amostragem de 99 processos. 
Segundo Osório, a redução da importância da criação de mulas da segunda metade do século xvIII para o primeiro quartel do Oitocentos parece estar vinculada, entre outras coisas, a duas razões capitais: 1) a difusão pecuária muar em outras áreas da América portuguesa localizadas mais próximas dos centros consumidores, como em São Paulo e nas Minas Gerais, e; 2) a instauração e consolidação inicial da indústria do charque, ocorridas a partir dos anos 1780, fatos que desencadearam o crescimento do consumo e produção de animais vacuns.

Figura 3. Frequência da coexistência de produção vacum e muar de acordo com a envergadura do rebanho bovino, Vila de São Borja

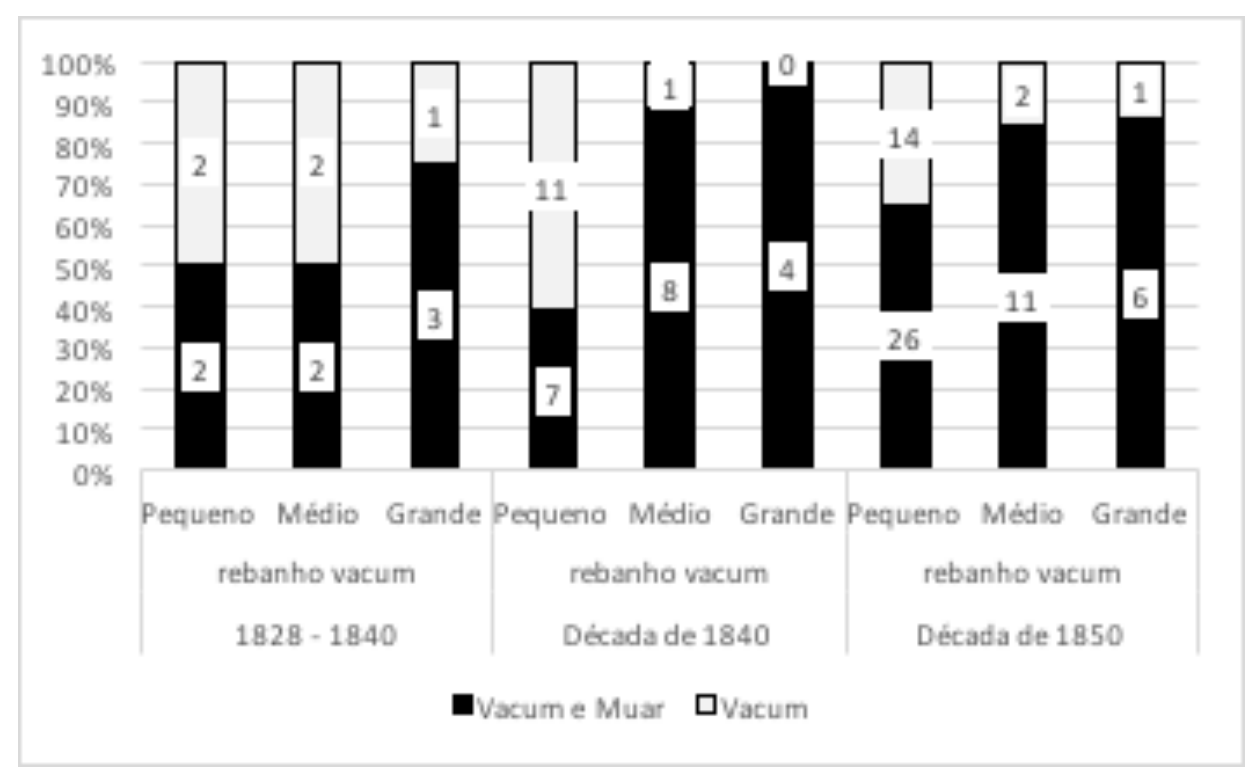

Fonte: Inventários post-mortem da Vila de São Borja (1828-1858) e do Distrito de São Patrício de Itaqui (1830-1858), APERS.

A figura 3 nos mostra a coexistência de ambas as criações ao longo das décadas analisadas. Em primeiro lugar, percebe-se que foi bastante comum entre os produtores da região, independente de sua envergadura, produzirem reses e mulas concomitantemente. No decorrer das três décadas analisadas, a criação de muares apresentou crescimento nas três faixas de criadores, o que sugere que os rendimentos provenientes de tal atividade não eram desprezíveis e despertavam o interesse até mesmo dos grandes criadores. Por meio da figura 3 se percebe que a existência mútua das duas criações sempre foi maior na faixa dos proprietários de grandes rebanhos bovinos, entre 1828 e 1830, 75\% deles também criavam mulas, enquanto que na década 1840 todos os grandes criadores de bovinos dedicavam-se à criação de mulas e no decênio seguinte $83 \%$. Obviamente que estes expressivos números proporcionais se devem também ao reduzido número absoluto de grandes criadores de vacuns. No entanto, mesmo que seu peso frente ao universo de criadores de mulas seja reduzido (da mesma forma que frente ao universo de criadores de gado vacum), no máximo 37,5\% entre 1828 e 1840 e por volta de 14\% na década de 1850 (ver figura 2), não deixa de ser significativo que ao longo de duas décadas seguidas mais de $83 \%$ dos grandes proprietários de bovinos da amostragem também se dedicassem à pecuária muar. Além disso, muito provavelmente, era deste grupo que provinha significativa parte da produção de mulas. 
Por outro lado, na mais numerosa faixa, a dos pequenos criadores de gado vacum, verificou-se uma flutuação dos índices entre as décadas. No primeiro recorte, verificou-se a coexistência das duas atividades em cerca de 50\% dos produtores, caindo a 39\% em 1840 e atingindo 65\% no último subperíodo examinado. Embora a variação negativa do primeiro para o segundo recorte, o índice de pequenos criadores de bovinos que também criavam mulas aumentou consideravelmente no decênio de 1850. Mesmo assim, em termos proporcionais os índices alcançados nesta faixa foram sempre inferiores do que os verificados para as outras duas.

Em meu entendimento, estes números sugerem que era mais difícil para os pequenos produtores manter as duas criações (bovina e muar) de maneira concomitantemente. Este quadro de maior dificuldade para os modestos produtores pode ser explicado pela significativa complexidade que envolvia as duas atividades produtivas, em especial a criação de mulas. Como já coloquei, a produção de muares é um processo bastante complexo. A mulas não nascem naturalmente como reses, ao contrário, para que ocorra o nascimento de uma mula se fazia necessário uma organização com inúmeras variáveis: o treinamento do burro hechor e das éguas para crias de mula; do mesmo modo era necessário ter burros e burras para produzir burros hechores e; por outro lado, possuir cavalos e éguas para produzir as éguas que seriam destinadas para a criação de mulas; ademais, tal processo demandava mais tempo e braços, pois era necessário promover o cruzamento do burro hechor e da égua. Enfim, sem dúvida, tratava-se de um processo com uma considerável especialização e que exigia uma organização mais metódica do que a produção de reses que, por sua vez, oferecia maiores rendimentos. Desta feita, seria mais fácil aos grandes e médios proprietários reunir condições estruturais para desenvolver tal atividade concomitantemente com a pecuária vacum, uma vez que organizar uma estrutura para criar mulas exigiria investir um volume considerável de recursos, o que seria mais difícil aos pequenos criadores. Diante disso, se um modesto produtor tivesse que necessariamente escolher entre criar gado vacum e mulas, provavelmente, escolheria criar o primeiro, pois seria menos dispendioso e obteria maiores rendimentos.

Porém, mesmo sendo mais difícil para os pequenos criadores empreenderem as duas criações conjuntamente, os dados não deixam dúvidas que criar mulas também esteve ao alcance de uma importante parcela dos modestos produtores da Vila de São Borja. Ao se decompor esta faixa em dois grupos, criadores com até 100 reses e aqueles que possuíam de 101 a 500 reses, percebe-se que no primeiro grupo 61\% (14 de 23) também criavam mulas, e no segundo eram 60\% (21 de 35) os que também produziam muares. Para Cruz Alta (1834 - 1879), Thiago Araújo constatou que no primeiro caso, 57,5\% dos criadores de reses também desenvolviam a pecuária muar, enquanto que no segundo caso 57,1\% deles se dedicavam a estas duas produções. Tendo em conta que os estudos como os de Zarth (1997, 2002), e também do próprio Araújo (2008), apontam que a pecuária muar teve maior destaque no Planalto do que em outras regiões da província, os dados examinados parecem sugerir que a criação de mulas na região das Missões no mínimo esteve bem próxima da envergadura que assumiu no Planalto. Também é preciso ponderar que os dados apresentados por Araújo consideram um período de tempo bem maior do que estou analisando nessa investigação, além disso, nas últimas três décadas da segunda metade do século XIX, a produção muar entrou em decadência devido à construção de ferrovias, sem dúvida, esta situação refletiu nos números expostos por Araújo.

A busca pela diversificação das atividades pecuárias parece ter sido a regra entre todas as faixas de criadores. Mesmo que a criação de mulas tenha sido mais frequente entre os médios 
e grandes produtores de gado vacum, os pequenos criadores, que sofriam com a limitação de recursos, também procuravam desempenhar ambas as atividades criatórias. Como viu-se, os pequenos criadores de animais vacuns representaram aproximadamente $50 \%$ dos criadores de mula. Desdobrando essa faixa em dois grupos de produtores: aqueles com rebanho entre 101 e 500 animais e outros de criadores com menos de 101 animais, constata-se que os produtores com menos de 101 animais vacuns eram 20\% (14 de 70) dos criadores de muares, sendo que sua proporção chegava a 40\% (14 de 35) entre a faixa de pequenos criadores de bovinos produtores de mulas.

Aqui se faz necessário levar em conta o que Helen Osório definiu para aqueles produtores que possuíam rebanhos com menos de 101 animais. A autora constatou que produtores com rebanhos menores do que 101 animais vacuns não podiam tirar o sustento para si e seu grupo familiar apenas com os rendimentos oriundos do pastoreio, ou seja, invariavelmente teriam que desenvolver outra atividade econômica, a qual, na grande maioria dos casos que analisou, era a agricultura. Com base no Censo de 1784, Osório verificou que "os produtores denominados como 'lavradores' possuíam, em média, 61 desses animais... [e] se dedicavam prioritariamente à agricultura" (2007, p. 105 [grifos da autora]); e dentre aqueles com menos de 101 animais, "82,6\% dos proprietários com ocupação declarada eram 'lavradores' e possuíam em média 37 cabeças de gado" (2007, p. 105 [grifos da autora]). ${ }^{16}$ Assim, se os criadores com menos de 101 animais vacuns tinham inevitavelmente que recorrer à outra atividade econômica para lograr o seu sustento e de seu grupo familiar, parece que na Vila de São Borja a pecuária muar se estabeleceu como uma importante e viável possibilidade produtiva para estes modestos produtores. Em termos gerais, vale destacar que para os camponeses pobres, as mulas configuravam-se como uma viável possibilidade de tornar suas existências menos vulneráveis diante das intempéries da vida e também de alcançar maior autonomia em relação aos estratos sociais hegemônicos que controlavam expressiva parte dos recursos econômicos e exerciam e/ou influenciavam o poder político em escalas variáveis (local ou em escala mais abrangente).

A análise destes dados quantitativos ajuda a apreender de maneira mais nítida o alcance social e econômico da pecuária muar na região em pauta. Mas tal condição não ficou expressa somente de forma indireta nos inventários post-mortem. Um relatório da Câmara de Vereadores de São Borja é bastante revelador sobre a importância que a produção de mulas adquiriu no município:

não merece menção especial o comércio de animais cavalares porque só é efetuado sua compra e venda no interior do Município em pequena escala, salvo nas ocasiões que são vendidos para (ilegível). Não acontece outro tanto com os vacuns e muares, cujo comércio é, destes últimos com especialidade apesar da baixa que tiveram, talvez a única fonte de onde se derrama maior porção de dinheiro no Município. ${ }^{17}$

16 Na nota 83 da página 113, a autora coloca ainda que "além de 464 'lavradores', encontravam-se nessa faixa (de até 100 cabeças de gado) pessoas com as seguintes ocupações: 'mais lavoura que criação' (41); 'criador' (21); 'planta para o sustento de sua casa' (10); artesão (10); 'criador e lavrador' (3)" (Osório, 2007, p. 113 [grifos da autora]).

17 Carta anexa ao Mapa demonstrativo das oficinas, estabelecimentos e fábricas do município de São Borja. Correspondência expedida pela Câmara de Vereadores da Vila de São Borja, 1858, Fundo Câmaras Municipais, Maço 
Segundo as informações prestadas pelas autoridades municipais, o processo produtivocomercial da criação de mulas erigia-se na principal fonte de recursos para os cofres da municipalidade. Fica patente, portanto, que todo o nicho produtivo que envolvia a pecuária muar tomou uma dimensão que repercutia de forma expressiva em inúmeras dimensões na dinâmica socioeconômica e institucional da Vila de São Borja. A julgar pelo que foi examinado até aqui, pude perceber a abrangência social da atividade criatória de muares, o seu papel estratégico na diversificação do complexo produtivo da região e na vinculação dos produtores da região ao circuito comercial da Feira de Sorocaba. ${ }^{18}$

Sobre este último aspecto, posso, mais uma vez, estabelecer um paralelo com o estudo de Mariana Canedo. Em sua análise, esta autora demonstra que a criação de mulas compunha "uma extensa cadeia que vincula os produtores de diferentes zonas da campanha com o polo mineiro [do Alto Peru]. Concentra de forma direta ou através de seus habilitados, mulas produzidas desde a Magdalena ao Arroyo do Meio por um arquipélago de criadores" (Canedo, 1993, p. 159)" [tradução livre]. Um cenário muito semelhante ocorria no complexo produtivo-comercial de mulas que ligava uma miríade de criadores de mulas que habitavam as áreas do oeste do Rio Grande de São Pedro, em especial a região da Missões e o planalto sul rio-grandense, com a Feira de Sorocaba na província de São Paulo, onde as mulas eram vendidas para comerciante e produtores de outras províncias do Império brasileiro.

\section{Considerações finais}

Os dados analisados mostram que a criação de mulas esteve bastante difundida pela região das Missões entre as décadas de 1830 e 1850. Na maioria dos estabelecimentos produtivos em que se produziam mulas, esta atividade dividia espaço com a pecuária bovina. Em comparação a esta, a criação de gado muar não atingiu a mesma monta econômica, no entanto, representou uma das estratégias mais viáveis para diversificar a produção e ampliar o espectro de possibilidades econômicas e produtivas dos produtores que buscavam se tornar menos vulneráveis diante as precariedades do universo agrário em que habitavam.

A disseminação da criação de mulas me leva a crer que se tratava de um ramo de produção comercialmente atrativo e economicamente viável. Portanto, acredito que os volumes de produção não se fizeram desprezíveis. Caso isso não tivesse ocorrido, uma atividade tão complexa, com considerável grau de especialização e investimento (monetário, de tempo, mão de obra) não teria se difundido por boa parte das unidades de produção.

As informações oriundas dos inventários post mortem indicam que cerca da metade dos produtores de mulas eram pequenos criadores de gado vacum. Numa perspectiva diacrônica, no decorrer do período considerado, o universo da pecuária muar passou a ser composto em sua maioria por modestos criadores de bovinos. Todavia, no que tange à posse do gado muar, creio que ela não seria muito diferente ao comportamento que se dava em relação à estrutura de posse do gado vacum. Provavelmente, a posse de mulas se caracterizaria pela existência de dois polos distintos, num deles estaria um expressivo contingente de pequenos criadores, que

233, Arquivo Histórico do Rio Grande do Sul [AHRS].

18 Sobre circuitos comerciais e de contrabando de mulas entre o Rio Grande de São Pedro e a Feira de Sorocaba no período colonial, ver Gil (2002, pp. 183-187; 2009, pp. 45-61); e Hameister (2002, pp. 74-77).

tiempo\&economía

Vol. 6 N. ${ }^{\circ} 2$ - Julio - Diciembre del 2019

p. 75 
dividiriam entre si uma pequena parte do rebanho muar, enquanto no outro, uma pequena elite de grandes criadores de mulas concentraria a maior parcela do rebanho.

Entretanto, foi nesta faixa dos modestos criadores que se verificou os menores índices de coexistência de pecuária muar e vacum numa mesma unidade produtiva. Entendo que isso tenha ocorrido em virtude da considerável complexidade que envolvia o desenvolvimento da criação de mulas. Isto é, para se criar mulas seria necessário dispor de um significativo volume de recursos, o que, por sua vez, fazia com que fosse mais difícil aos pequenos criadores estabelecer a estrutura produtiva exigida pela pecuária muar. Sendo assim, frente à limitação de recursos, determinada parcela dos modestos produtores não tiveram condições de desenvolver a pecuária muar, ou ao menos preferiram criar gado vacum, uma atividade menos complexa, que exigia menores investimentos e que garantia um maior retorno do que a criação de mulas. Por outro lado, os dados mostram que ao longo do tempo médios e grandes produtores cada vez mais passaram a conciliar a pecuária bovina com a criação de mulas, transformando tal atividade numa importante alternativa para a diversificação das atividades produtivas na região das Missões.

Ao cotejar as fontes e outras pesquisas que tiveram como sítio de pesquisa regiões vizinhas a Vila de São Borja, pude perceber que, em termos dimensionais, a pecuária muar na referida região era maior do que a praticada na Vila de Alegrete, equiparando-se a dimensão que adquiriu no Planalto (Vila de Cruz Alta), região que havia se tornado em um importante entreposto do circuito comercial da Feira de Sorocaba, onde o gado muar era comercializado. Enfim, posso argumentar que embora a criação de bovinos tenha sido a atividade produtiva predominante e mais rentável, a criação de mulas se conformou numa importante alternativa para que os criadores diversificassem sua produção, se vinculassem ao circuito da Feira de Sorocaba e não ficassem restritos as demandas do fluxo comercial de reses do complexo porto-charqueador do leste do Rio Grande de São Pedro.

\section{REFERÊNCIAS}

Araújo, T. de. (2008). Escravidão, fronteira e liberdade: políticas de domínio, trabalho e luta em um contexto produtivo agropecuário (vila de Cruz Alta, província do Rio Grande do Sul, 1834-1884). Dissertação de Mestrado. PPGH/UFRGS, Porto Alegre, RS.

Barros, J. (2012). A história serial e história quantitativa no movimento dos Annales. História Revista, 17(1), 203-222 < https://doi.org/10.5216/hr.v17i1.21693>.

Bragoni, B. (2004). Microanálisis: ensayos de historiografía argentina. Buenos Aires: Prometeo Libros.

Borges, L. A. (2016). Mulas em movimento: o mercado interno brasileiro e o negócio de tropas, primeira metade do século XIX. Anos 90, 23(44), 207-230<https://doi.or$\mathrm{g} / 10.22456 / 1983-201 X .55886>$.

Burke, P. (1991). A Escola dos Annales, 1929-1989: a Revolução Francesa da Historiografia. São Paulo: EDUSP. 
Canedo, M. (1993). La ganadería de mulas en la campaña bonaerense. Una aproximación a las estrategias de producción y comercialización en la segunda mitad del siglo XVIII. En R. Mandrini \& A. Reguera (Orgs.), Huellas en la tierra. Indios, agricultores y hacendados en la pampa bonaerense (pp. 147-160). Tandil: IEHS.

Carbonari, M. (2013). Historia regional y microhistoria. Aproximaciones a lo particular. [Re] construcciones. En Anuario del Centro de Investigaciones históricas de la Universidad Nacional de Río Cuarto 1 (pp. 47-60).

Carneiro, D. (1983). História da Guerra Cisplatina. Brasilia: Editora da UnB.

Chiaramonte, J. C. (1997). Ciudades, provincias, Estados: orígenes de la nación argentina, 18001846. Buenos Aires: Ariel.

Dacanal, J. (1997). A Revolução Farroupilha: História e Interpretação. Porto Alegre, RS: Mercado Aberto.

Djenderedjian, J. (2003). Historia del capitalismo agrario pampeano: la expansión ganadera hasta 1895. Buenos Aires: Siglo Veintiuno.

Dosse, F. (1992). A História em Migalhas: dos Annales à Nova História. Campinas, SP: Editora da Unicamp.

Espada Lima, H. (2005). Sob o domínio da precariedade: escravidão e os significados da liberdade de trabalho no século XIX. Topoi, 6(11), 289-325<http://dx.doi.org/10.1590/2237-101X006011004>.

Faria, S. de C. (1998). A Colônia em Movimento: fortuna e família no cotidiano colonial. Rio de Janeiro: Nova Fronteira.

Farinatti, L. (2010). Confins Meridionais: famílias de elite e sociedade agrária na fronteira sul do Brasil. Santa Maria, RS: Editora da UFSM.

Fernández, S. (2007). Más allá del territorio. La historia regional y local como problema. Discusiones, balances y proyecciones. Rosario: Prohistoria ediciones.

Fernández, S., \& Dalla Corte, G. (2005). Lugares para la historia: espacio, historia regional e historia local en los estudios contemporáneos. Rosario: UNR Editora.

Fontella, L. (2013). Sobre as ruínas dos Sete Povos: estrutura produtiva, escravidão e distintos modos de trabalho no espaço oriental missioneiro. Vila de São Borja, Rio Grande de São Pedro, c.1828 - c.1860. Dissertação de Mestrado. PPGH/UFRGS, Porto Alegre, RS.

Fontella, L. (2014). O Pastorio bovino na região das Missões (Rio Grande de São Pedro, 1828 1858). Anos 90, 21(40), 389-423 <https://doi.org/10.22456/1983-201X.41119>.

Fragoso, J. (1992). Homens de Grossa Aventura: acumulação e hierarquia na praça mercantil do Rio de Janeiro, 1790-1830. Rio de Janeiro: Arquivo Nacional.

Frega, A. (1998). La virtud y el poder: la soberanía particular de los pueblos en el proyecto Artiguista. In N. Goldman \& R. Salvatore (Orgs.), Caudillismos rioplatenses. Nuevas miradas a un viejo problema (pp. 101-133). Buenos Aires: EUDEBA.

Frega, A. (Org.) (2009). Historia regional e independencia del Uruguay: proceso histórico y revisión crítica de sus relatos. Montevideo: Ediciones de la Banda Oriental. 
Garavaglia, J. (1999). Pastores y labradores de Buenos Aires: una historia agraria de la campaña bonaerense, 1700-1830. Buenos Aires: Ediciones de la Flor.

Gelman, J. (1998). Campesinos y estancieros. Una región del Rio de la Plata a fines de la época coIonial. Buenos Aires: Editorial Los Libros del Riel.

Gil, T. (2002). Infiéis transgressores: os contrabandistas da fronteira, 1760-1810. Dissertação de Mestrado. PPGHIS/UFRJ, Rio de Janeiro.

Gil, T. (2009). Coisas do caminho: tropeiros e seus negócios do Viamão à Sorocaba. Tese de doutorado. PPGHIS/UFRJ, Rio de Janeiro.

Gil, T. (2001). La historiografía agraria argentina: enfoques microhistóricos regionales para la macrohistoria rural del siglo XX, 1980-1999. Revista Estudios Interdisciplinarios de América Latina y el Caribe, 12(2), 5-34.

Gil, T. (2006). La historia regional de hoy: balances y perspectivas con enfoque agrario. En J. Gelman (comp.), La historia económica argentina en la encrucijada: balances y perspectivas (pp. 411-424). Prometeo Libros.

Gil, T. (2007). Vigencia de las tramas regionales en la historia de la Argentina rural, En O. Graciano \& S. Lazzaro (comps.), La Argentina rural del siglo xx: fuentes, problemas y métodos (pp. 41-54). Buenos Aires: La Colmena.

Hameister, M. (2002). O Continente do Rio Grande de São Pedro: os homens, suas redes de relações e suas mercadorias semoventes. Dissertação de Mestrado. PPGHIS/UFRJ, Rio de Janeiro.

Isabelle, A. (2006). Viagem ao Rio da Prata e ao Rio Grande do Sul. Brasília, DF: Senado Federal.

Irigoin e Schmit (eds.). (2003). La desintegración de la economía colonial. Comercio y moneda en el interior del espacio colonial (1800-1860). Buenos Aires: Editorial Biblos.

Leitman, S. (1979). Raízes sócio-econômicas da Guerra dos Farrapos. Rio de Janeiro (RJ): Graal.

Levi, G. (2000). Herança Imaterial: trajetória de um exorcista no Piemonte do século XVII. Rio de Janeiro: Civilização Brasileira.

Linhares, M. (1997). História Agrária. In C. Cardoso \& R. Vainfas (orgs.), Domínios da história: ensaios de teoria e metodologia. Rio de Janeiro: Elsevier.

Márquez, M. (2008). Grupos de mercaderes cordobeses en el espacio peruano: la incidencia de las reformas borbónicas y las sublevaciones indígenas. Anais das 21 a Jornadas de História Económica.

Mattos, H. (1997). História Social. Em Domínios da história: ensaios de teoria e metodologia (pp. 76-96). Rio de Janeiro (RJ): Elsevier.

Mattos, H. (1995). Das cores do silêncio: os significados da liberdade no sudeste escravista, Brasil, século XIX. Rio de Janeiro: Arquivo Nacional.

Mattos, H. (2009). Ao sul da história: lavradores pobres na crise do trabalho escravo. São Paulo: Braziliense. 
Moreyra, B. (1992). La producción agropecuaria cordobesa, 1880-1930. Córdoba: Centro de Estudios Históricos.

Osório, H. (2007). O império português ao sul da América: estancieiros, lavradores e comerciantes. Porto Alegre, RS: Editora da UFRGS.

Paz, G. (1999). A la sombra del Perú: mulas, repartos y negocios en el norte argentino a fines de la colônia. Boletin del Instituto de Historia argentina y americana Dr. Emilio Ravignani, 3(20), 45-68.

Pessoa, M. (org.). (2017). Atlas FEE. Porto Alegre: FEE.

Reis, J. (2000). Escola dos Annales: a Inovação em História. São Paulo: Paz e Terra.

Richard-Jorba, R. y Bonaudo, M. (2014). Historia regional. Enfoques y articulaciones para complejizar una historia nacional. La Plata: Universidad Nacional de La Plata.

Schmit, R. (2008). Historia del capitalismo agrario pampeano: Tomo 5: Los límites del progreso: expansión rural en los orígenes del capitalismo rioplatense. Buenos Aires: Siglo Veintiuno.

Suprinyak, C., \& Restitutti, C. (2006). Os muares e as Minas: relações entre a demanda mineira e o mercado de animais de carga nos séculos XVIII e XIX. Anais do XII Seminário sobre a Economia Mineira.

Wilde, G. (2009). Religión y poder en las misiones guaraníes. Buenos Aires: SB.

Zarth, P. (1997). História agrária do planalto gaúcho, 1850-1920. Ijuí (RS): Editora da Unijuí.

Zarth, P. (2002). Do Arcaico ao Moderno: as transformações no Rio Grande do Sul rural do século XIX. Passo Fundo, RS: Editora da UPF. 